\title{
Distribution of glutathione S-transferase GSTM1 and GSTT1 null phenotypes in Brazilian Amerindians
}

\author{
Maria de Nazaré Klautau-Guimarães ${ }^{1}$, Cássia de Oliveira Hiragi ${ }^{1}$, Renata Ferreira D’Ascenção ${ }^{1}$, \\ Silviene Fabiana Oliveira ${ }^{1}$, Cesar Koppe Grisolia ${ }^{1}$, Ana Hatagima ${ }^{2}$ and Íris Ferrari ${ }^{1}$ \\ ${ }^{1}$ Universidade de Brasília, Instituto de Ciências Biológicas, Departamento de Genética e Morfologia, \\ Brasilia, DF, Brazil. \\ ${ }^{2}$ Instituto Oswaldo Cruz, Departamento de Genética, Pavilhão Leônidas Deane, Rio de Janeiro, RJ, Brazil.
}

\begin{abstract}
The distribution of glutathione S-transferase (GST) GSTM1 and GSTT1 null phenotype frequencies in two Brazilian Amerindian tribes, the Munduruku tribe from Missão Cururu village (79 individuals) and the Kayabi tribe (41 individuals), was analyzed by polymerase chain reaction (PCR) amplification. The GST null phenotype frequencies for the Munduruku sample were 0\% for GSTM1 and 27\% for GSTT1 while for the Kayabi sample the null phenotype frequencies were $27 \%$ for GSTM1 and $29 \%$ for GSTT1. This is the first report of the absence of the GSTM1 null phenotype in any ethnic group.
\end{abstract}

Key words: Munduruku, glutathione S-transferase, Kayabi, null alleles.

Received: July 25, 2003; Accepted: May 3, 2004.

Glutathione S-transferases (GSTs) are a superfamily of enzymes that are involved in the detoxification of reactive metabolites of carcinogens and may therefore be important in modulating susceptibility to cancers. Four polymorphic families of cytosolic soluble GSTs have been identified in humans, the alpha family on chromosome 6, the $m u$ family on chromosome 1 , the theta family on chromosome 22 and the pi family on chromosome 11 (Mitrunen et al., 2001; Strange et al., 2001). Five $m u$ class genes are situated in tandem (5' - GSTM4-GSTM2-GSTM1-GSTM5GSTM3 - 3') in a $20 \mathrm{~kb}$ cluster on chromosome $1 \mathrm{p} 13.3$ (Pearson et al., 1993). Polymorphism has been identified in the $m u$ class GSTM1 with three alleles $\left(G S T M 1{ }^{*} 0\right.$, $G S T M 1{ }^{*} A$ and $\left.G S T M 1{ }^{*} B\right)$, of which $G S T M 1 * 0$ is a null allele consisting of the complete deletion of the GSTM1 gene. Individuals who are homozygous for this allele are unable to produce the GSTM1 protein. Due to the high frequency (40-60\%) of the GSTM1 0/0 genotype in most analyzed populations, which varies among ethnic groups (Board, 1981; Mikelsaar et al., 1994; Zhao et al., 1994), the allelic distribution of this gene has been widely studied. Another gene, the theta class GSTT1, located on chromosome 22 (Coggan et al., 1998), is also polymorphic and

Send correspondence to Maria de Nazaré Klautau-Guimarães. Universidade de Brasília, Instituto de Ciências Biológicas, Departamento de Genética e Morfologia, ICC Sul - Sala AT98, 70910-900 Brasília, DF, Brazil. E-mail: nklautau@unb.br. presents two alleles, GSTT1* 1 active allele and the GSTT1*0 null gene. Like GSTM1, GSTT1*0 is a non-functional allele resulting from the deletion of the GSTT1 gene, with GSTT1 0/0 (or null) phenotype individuals being unable to produce the GSTT1 protein (Pemble et al., 1994). The homozygous GSTT1 null phenotype has been described in different populations and shows wide variation (Nelson et al., 1995). The GSTM1 and GSTT1 loci are candidates as cancer susceptibility genes because they are related to metabolism and prone to induction by numerous known or suspected carcinogenic compounds (Rebbeck, 1997; Hayes and Strange, 2000).

Knowledge of the distributions of these alleles in different populations is important for the investigation of polymorphisms as risk factors in epidemiological studies, related to their geographic and inter-ethnic variation frequency. Arruda et al. (1998) and Gaspar et al. (2002) have already described some data for Brazilian populations. In this paper we describe the phenotypic distribution of the GSTT1 and GSTM1 polymorphisms in the Kayabi and Munduruku tribes, two geographically distinct indigenous Brazilian populations.

In 2000 blood samples were collected from individuals belonging to the Kayabi and Munduruku Brazilian Amerindian tribes. The Kayabi tribe is located on the right margin of the Teles Pires River in the Brazilian state of Mato Grosso (55 40 $\left.60^{\prime \prime} \mathrm{W}, 11^{\circ} 37^{\prime} 0^{\prime \prime} \mathrm{S}\right)$ and has a population of about 1,000 individuals; blood samples being col- 
lected from 21 males and 20 females with a median age of 24.53 years. The Munduruku tribe is located in Pará state (57 34'60' W, $7^{\circ} 37^{\prime} 0^{\prime}$ ' $\mathrm{S}$ ) and has an estimated population of 3,000, blood samples being collected, with EDTA as anticoagulant, from 38 males and 41 females with a median age of 30.9 years who were living in Missão Cururu village. Amerindian populations generally have a high level of endogamy, because of which we only sampled individuals with no first-degree (parent-offspring) relationship (Rodrigues et al. (2002). More details about these tribes can be found in the book 'Demarcando Terras Indígenas II' by Rodrigues et al. (2002).

DNA was isolated from the buffy-coat layer using the $G F X^{T M}$ Genomic Pharmacia Kit and stored at $-20^{\circ} \mathrm{C}$ until analysis. The glutathione S-transferase (GST) GSTM1 and GSTT1 fragments were amplified using a PCR protocol modified from Fryer et al. (1993) for GSTM1 and Kempkes et al. (1996) for GSTT1. Phenotypes were determined by electrophoresis of the PCR fragments in $2 \%$ agarose gel stained with ethidium bromide. The GSTM1 gene was confirmed by amplification of a 132 bp fragment and GSTT1 by amplification of a $480 \mathrm{bp}$ fragment, homozygotes for the deleted genes did not present these amplified fragments. The success of the amplification was confirmed by the presence of a $268 \mathrm{bp}$ DNA fragment of $\beta$-globin as an internal positive control. Two phenotypic groups (previously called conjugator and non-conjugator when analyzed by conjugation reactions) were identified for both the GSTM1 and GSTT1 genes, e.g. the GSTT1+ phenotype (GSTT1+/+ and GSTT1+/0) and the GSTT1 null phenotype
(GSTT10/0) for the GSTT1 gene and likewise for the GSTM1 gene.

The GSTM1 and GSTT1 null phenotype frequencies and the combined GSTM1 null + GSTT1 null phenotype frequencies in the Kayabi and Munduruku samples along with information on other Brazilian Amerindian tribes and the Paraguayan Ache tribe are given in Table 1. The distribution of GSTM1 and GSTT1 phenotypes appears to be heterogeneous for Brazilian Amerindian populations.

The GSTM1 null phenotype frequencies vary from $38 \%$ to $67 \%$ in European populations, from $33 \%$ to $63 \%$ in Asians and from $22 \%$ to $35 \%$ in Africans and AfricanAmericans (Rebbeck, 1997; Garte et al., 2001). In Brazilian urban populations, the GSTM1 null phenotype frequency varies from $46 \%$ to $49 \%$ (Hatagima et al., 2000). In this study we found that the GSTM1 null phenotype did not occur at all in the Munduruku sample. This population was monomorphic for GSTM1 with all individuals presenting the positive phenotype, indicating that they have at least one active allele. The lowest GSTM1 null phenotype frequency previously reported was the $3.9 \%$ detected in Guarani Amerindians by Gaspar et al. (2002), which contrasts with the GSTM1 null phenotype frequency of the Pacific island Kiribati tribe where the population seems to be monomorphic for the homozygous deletion (Rebbeck, 1997). On the other hand, we found that the Kayabi population presented a GSTM1 null homozygote frequency of $27 \%$, which is close to the $20 \%$ frequency found in the Parakanã Amerindians by Arruda et al. (1998). Gaspar et al. (2002) found values varying from 4 to $43 \%$ in seven Amerindian populations (Table 1). The GSTM1 null phe-

Table 1 - Distribution of the glutathione S-transferase (GST) GSTM1 null and GSTT1 null genotypic frequencies in different Amerindian populations.

\begin{tabular}{|c|c|c|c|c|c|}
\hline \multirow[b]{2}{*}{ Amerindian tribe } & \multirow[b]{2}{*}{ Geographic localization } & \multicolumn{3}{|c|}{ Genotypic frequencies (\%) } & \multirow[b]{2}{*}{$\mathrm{N}$} \\
\hline & & GSTM1 null & GSTT1 null & GSTM1 null + GSTT1 null & \\
\hline \multicolumn{6}{|l|}{ Present paper } \\
\hline Kayabi & Mato Grosso state, Brazil & 27.0 & 29.0 & 15.0 & 41 \\
\hline Munduruku & Pará state, Brazil & 0.0 & 27.0 & 0.0 & 79 \\
\hline \multicolumn{6}{|c|}{ Arruda et al. (1998) } \\
\hline Parakanã & Pará state, Brazil & 20.0 & 11.0 & 5.0 & 79 \\
\hline \multicolumn{6}{|c|}{ Gaspar et al. (2002) } \\
\hline Wai Wai & Pará state, Brazil & 26.9 & 0.0 & NA & 26 \\
\hline Zoró & Mato Grosso state, Brazil & 14.3 & 14.3 & NA & 28 \\
\hline Surui & Rondônia state, Brazil & 43.0 & 0.0 & NA & 21 \\
\hline Gavião & Rondônia state, Brazil & 12.9 & 6.5 & NA & 31 \\
\hline Xavante & Mato Grosso state , Brazil & 18.2 & 30.3 & NA & 33 \\
\hline Guarani & Mato Grosso do Sul state, Brazil & 3.9 & 11.8 & NA & 51 \\
\hline Ache & Paraguay & 35.8 & 17.9 & NA & 67 \\
\hline
\end{tabular}

$\mathrm{NA}=$ Data not available 
notype frequency in the Kayabi was similar to the Wai Wai population frequency (27\%), but lower than the frequencies described for the Aché (36\%) and Surui (43\%) tribes (Gaspar et al., 2002). The estimated allelic frequencies for GSTM1 null were 0.00 in the Munduruku and 0.52 in the Kayabi. This is the most extreme value reported so far for any ethnic group, including the $4 \%$ detected among the Guarani Amerindians (Gaspar et al., 2002).

In the Kayabi tribe the prevalence of GSTT1 null homozygotes was $29 \%$ and the allelic frequency was 0.54 while in the Munduruku tribe the GSTT1 null homozygote prevalence was $27 \%$ and the allelic frequency 0.52 . These null phenotype frequencies are higher than those found in most other Amerindian tribes, the exception being the Xavante tribe where the prevalence of GSTT1 null homozygotes has been shown to be slightly above 30\% (Arruda et al., 1998; Gaspar et al., 2002). Values for Brazilian urban groups vary from $18.5 \%$ to $36 \%$ and for world populations in general from $20 \%$ to $47 \%$ (Arruda et al., 1998; Hatagima et al., 2004; Fonte de Amorim et al., 2002).

The frequency of the two null phenotypes (GSTM1 null + GSTT1 null) in the same individual was $15 \%$ in the Kayabi sample and $0 \%$ in the Munduruku sample (Table 1). The $15 \%$ observed in the Kayabi tribe is similar to that found in Brazilian Caucasians (Arruda et al., 1998; Fonte de Amorim et al., 2002) but higher than the 5\% reported by Arruda et al., (1998) for the Parakanã tribe, the only other Amerindian group for which the GSTM1/T1 double-null frequency is described.

This is the first report of the absence of the GSTM1 null phenotype, and this should be further investigated to determine the possible causes and their significance for the Munduruku tribe. Stochastic factors, (e.g. bottleneck and founder effects, very common in Amerindian tribes) or other factors such as environmental adaptation, inbreeding, admixture with other ethnic groups or geographic distribution may explain the differences seen in this study but more research is needed to explore these questions more fully.

\section{Acknowledgments}

The authors thank the Brazilian Fundação Nacional do Índio (FUNAI), the German Deutsche Gesellschaft für Technische Zusammenarbeit (GTZ), and the Universidade de Brasília. This project was approved by the ethics committee of the Faculdade de Saúde of University of Brasília.

\section{References}

Arruda VR, Grinolli CE, Gonçalves MS, Soares MC, Menezes R, Saad STO and Costa FF (1998) Prevalence of homozygozity for the deleted alleles of glutathione S-transferase $\mathrm{mu}$ (GSTM1) and theta (GSTT1) among distinct ethnic groups from Brazil: Relevance to environmental carcinogenesis. Clin Genet 54:210-214.

Board PG (1981) Biochemical genetics of glutathione Stransferase in man. Am J Hum Genet 33:36-43.
Coggan M, Whitbread L, Whittngton A and Board P (1998) Structure and organization of the human theta-class glutathione S-transferase and D-dopachrome tautomerase gene complex. Biochem J 334:617-623.

Fonte de Amorim L, Rossini A, Mendonça G, Lotsch P, de Almeida Simão T, de Moura Gallo C and Pinto L (2002) CYP1A1, GSTM1, and GSTT1 polymorphisms and breast cancer risk in Brazilian women. Cancer Lett 26:179-86.

Fryer AA, Zhao L, Alldersea J, Pearson WR and Strange RC (1993) Use of site-directed mutagenesis of allele-specific PCR primers to identify the GSTM1A, GSTM1B, GSTM1AB and GSTM1 null polymorphisms at the glutathione S-transferase, GSTM1 locus. Biochem J 295:313-315.

Gaspar PA, Hutz MH, Salzano FM, Hill K, Hurtado AM, Petzl-Erler ML, Tsuneto LT and Weimer TA (2002) Polymorphisms of CYP1A1, CYP2E1, GSTM1, GSTT1 and TP53 genes in Ameridians. Am J of Phys Anthr 119:249-256.

Garte S, Gaspari L, Alexandrie AK, Ambrosone C, Autrup H, Autrup JL, Baranova H, Bathum L, Benhamou S, Boffetta P, Bouchardy C, Clapper LM, Coutelle C, Daly A, Dell'Omo M, Dolzan V, Dresler CM, Fryer A, Haugen A, Hein DW, Hildesheim A, Hirnoven A, Hsieh LL, Ingelman Sundberg M, Kalina I, Kang D, Kihara M, Kiyohara C, Kremers P, Lazarus P, Marchand LL, Lechner MC, VanLieshout MM, London S, Manni JJ, Maugard, CM, Morita S, Nazar Stewart V, Noda K, Oda Y, Parl FF, Pastorelli R, Persson I, Peters WHM, Rannug A, Rebbeck R, Risch A, Roelandt L, Romkes M, Ryberg D, Salagovic J, Schoket B, Seidegard J, Shieds PG, Sim E, Sinnet D, Strange RC, Stücker I, Sugimura H, To-Figueras, Jvineis P, Yu MC and Taioli E (2001) Metabolic gene polymorphism frequencies in control populations. Canc Epid Biomarkers \& Prevention 10:12391248.

Gramkow MM (2002) Demarcando terras indígenas II experiências e desafios de um projeto de parceria FUNAI/PPTAL/ GTZ, Brasília.

Hatagima A, Klautau-Guimarães MN, Silva FP and Cabello PH (2000) Glutathione S-transferase M1(GSTM1) polymorphism in two Brazilian populations. Genet Mol Biol 23:709-713.

Hatagima A, Marques CFS, Krieger H and Feitosa MF (2004) Glutathione S-tranferase M1 (GSTM1) and T1 (GSTT1) polymorphisms in a Brazilian mixed population. Human Biology (in press).

Hayes DJ and Strange RC (2000) Glutathione S-transferase polymorphisms and their biological consequences. Pharmacology 61:154-166.

Kempkes M, Golka K, Reich S, Reckwitz T and Bolt HM (1996) Glutathione S-transferase GSTM1 and GSTT1 null genotypes as potential risk factors for urothelial cancer of the bladder. Arch Toxicol 71:123-126.

Lee EJ, Wong JY, Yeoh PN and Gong NH (1995) Glutathione S transferase-theta (GSTT1) genetic polymorphism among Chinese, Malays and Indians in Singapore. Pharmacogenetics 5:332-334.

Mikelsaar AV, Tasa G, Pärlist P and Uusküla M (1994) Human glutathione S-transferase GSTM1 genetic polymorphism in Estonia. Hum Hered 44:248-251. 
Mitrunen K, Jourenkova N, Kataja V, Eskelinen M, Kosma VM, Benhamou S, Vainio H, Uusitupa M and Hirnoven A (2001) Glutathione S-Transferase $M 1, M 3, P 1$, and $T 1$ genetic polymorphisms and susceptibility to breast cancer. Can Epid Biomarkers \& Prevention 10:229-236.

Nelson HH, Wiencke JK, Christiani DC, Cheng TJ, Zuo ZF, Schwartz BS, Lee BK, Spitz MR, Wang M, Xu X and Kelsey KT (1995) Ethnic differences in the prevalence of the homozygous deleted genotype of glutathione Stransferase theta. Carcinogenesis 16:1243-1245.

Pearson WR, Vorachek WR, Xu SJ, Berger R, Hart I, Vannais D and Patterson (1993) Identification of class-mu glutathione transferase genes GSTM1-GSTM5 on human chromosome 1p13. Am J Hum Genet 53:220-33.

Pemble S, Schroeder KR, Spencer SR, Meyer DJ, Hallier E, Bolt HM, Ketterer B and Taylor JB (1994) Human glutathione S-transferase theta (GSTT1): cDNA cloning and the characterization of a genetic polymorphism. Biochem J 300:271276.
Rebbeck TR (1997) Molecular epidemiology of the human glutathione S-transferase genotypes GSTM1 and GSTT1 in cancer susceptibility. Cancer Epidemiol Biomarkers Prev 6:733-743.

Rodrigues P, Barbosa AC, Ferrari I, Souza JR and (2002) Avaliação da contaminação por mercúrio na terra indígena dos Mundurukus do Pará. In: Gramkow MM (ed), Demarcando Terras Indígenas II Experiências e Desafios de um Projeto de Parceria FUNAI/PPTAL/GTZ, Brasília. Deutsche Gesellschaft fur Technische Zusammenarbeit (GZT), GmbH, pp 123-148.

Strange RC, Spiteri M, Ramachandran S and Fryer AA (2001) Glutathione S-transferase family of enzymes. Mut Res 482:21-26.

Zhao L, Alldersea J, Fryer AA, Tighe A, Ollier B, Thomson W, Jones P and Strange RC (1994) Polymorphism at the glutathione S-transferase GSTM1 locus: A study of the frequencies of the GSTM1A, BA/B and null phenotypes in Nigerians. Clin Chim Acta 225:85-88.

Associate Editor: Francisco Mauro Salzano 